This is the author's final, peer-reviewed manuscript as accepted for publication. The publisher-formatted version may be available through the publisher's web site or your institution's library.

\title{
An initial lexicon of sensory properties for nail polish
}

Chen Sun, Kadri Koppel, and Edgar Chambers IV

\section{How to cite this manuscript}

If you make reference to this version of the manuscript, use the following information:

Sun, C., Koppel, K., \& Chambers, E. (2014). An initial lexicon of sensory properties for nail polish. Retrieved from http://krex.ksu.edu

\section{Published Version Information}

Citation: Sun, C., Koppel, K., \& Chambers, E. (2014). An initial lexicon of sensory properties for nail polish. International Journal of Cosmetic Science, 36(3), 262-272.

Copyright: (C) 2014 Society of Cosmetic Scientists and the Société Française de Cosmétologie

Digital Object Identifier (DOI): doi:10.1111/ics.12123

Publisher's Link: http://onlinelibrary.wiley.com/doi/10.1111/ics.12123/full

This item was retrieved from the K-State Research Exchange (K-REx), the institutional repository of Kansas State University. K-REx is available at http://krex.ksu.edu 


\title{
An Initial Lexicon of Sensory Properties for Nail Polish
}

\author{
Chen Sun, Kadri Koppel*, and Edgar Chambers IV
}

The Sensory Analysis Center, Kansas State University, 1310 Research Park, Manhattan, KS, 66502, U.S.A. Tel.: 785-532-0163; fax: 785-532-3132; e-mail: csun@k-state.edu, kadri@ksu.edu,eciv@ksu.edu.

*Corresponding author: Kadri Koppel. The Sensory Analysis Center, Kansas State University, 1310 Research Park, Manhattan, KS, 66502, U.S.A. Tel.: 785-532-0163; fax: 785-532-3132; email: kadri@ksu.edu. 


\section{Synopsis}

OBJECTIVE: The objective of this study was to develop an initial lexicon for sensory properties of nail polish and to validate this lexicon using a descriptive analysis study of selected samples.

METHODS: Seventeen commercial products from four categories (regular, flake-containing, water-based and gel) were used in this study. Descriptive sensory analysis was conducted in this study to characterize and evaluate application and removal properties of these nail polishes. Data was then processed by Analysis of Variance (ANOVA), Principal Component Analysis (PCA) and Pearson's Correlation Coefficient analysis to explore the differences among samples and attributes.

RESULTS: A lexicon of twenty-one sensory attributes was developed to describe the application of nail polish. It included three initial texture attributes, thirteen initial appearance attributes and five aroma attributes. A lexicon of five attributes in five stages was developed to describe the removal of nail polish. The results from ANOVA and PCA showed that attributes in the lexicon separated the different product categories.

CONCLUSION: The results of this study indicated that descriptive sensory analysis can be used to evaluate nail polish. The results of this study present scientists who are working on nail polish an additional tool to describe application and removal properties of nail polish.

Keywords: nail polish, sensory, descriptive analysis, nail physiology, statistics, Colour cosmetics 


\section{Introduction}

Cosmetics play an important role in our daily life. Time.com [1] reported that the nail care industry has been one of beauty's fastest-growing sectors in recent years and has encountered trends such as decorative treatments and textured polishes. Women's Wear Daily reports nail polish sales hit a record $\$ 768$ million in the U.S. in 2012, a 32\% gain over 2011[2]. This has probably happened because of uncertain economics, as consumers are looking for more affordable solutions for a manicure and opt for at-home treatments instead of salon services.

Several papers have been published on the physical aspects of nail polish. In 1981, Schlossman discussed techniques to evaluate the physical properties of nail polish. For example, a Taber Abraser or similar instrument is used to measure abrasion resistance through the action of two resilient abrading wheels which are made to rub the coated surface [3]. In 1993, Schlossman and Wimmer discussed new techniques such as employing acetone or halogenated hydrocarbons as the solvents to develop a quick drying nail polish, pouring nail enamel onto an adhesive-backed sheet of paper to make a non-brushing nail polish, and changing the ingredients to develop a water-dilutable nail polish [4]. A similar product, called "water-based nail polish" had been patented a year earlier by Koch and Rassek [5]. In 2000, Mui and et al. developed an internal flow time release formula by optimizing the film characteristics of conventional quick dry nail polish. This formula was able to provide consistent performance over a wide range of temperatures, oil content and surface abrasion of human nails [6].

As is common in the cosmetics and also other industries, most innovations in the nail polish sector are patented. Examples of innovations closely related to nail polishes are abundant; these include creation and implantation of an artificial nail [7], a foam applicator for nail polish [8], and a patent for a packaging and applicator device [9]. There are also several patented nail 
polish inventions, such as a top coat system [10], UV-curable nail coating formulations [11], and nail strips [12], among others.

According to Parente et al., understanding the sensory properties of emollients may help provide important information to the development of cosmetics [13]. However, scientific articles on the sensory properties of nail polish are scarce, which suggests the information is proprietary. One of the few such publications studied correlations between judgment and nervous system response using cosmetic products, including nail polishes [14]. Other cosmetics, such as spa spring waters [15], talc slips [16], personal care products [17], emollients [13], and lipstick [18] have been studied using sensory analysis methods. Thus, this study could provide important information on the sensory properties of nail polishes scientists who are interested in improving human perceived sensory aspects of the application, finish, and removal of nail polish.

The objective of this study was to develop a lexicon for application, appearance, and removal properties of nail polish and to validate the lexicon using descriptive sensory analysis.

\section{Materials and Methods}

\section{Panelists}

Six panelists from the Sensory Analysis Center at Kansas State University participated in this study. All panelists had received more than $120 \mathrm{~h}$ of descriptive analysis training, and had more than 2000h of descriptive analysis experience, including evaluating nonfood products such as lipstick [18] and textiles [19, 20].

\section{Samples and Carriers}

Seventeen commercial nail polishes were used to develop and validate the lexicon (Table I). Only red nail polish products were evaluated to reduce the effect of different colors on nail 
polish sensory attributes. The products were 9 regular nail polishes and three categories of specialty products, including gel nail polishes $(n=4)$, water-based nail polishes $(n=2)$, and flakecontaining nail polishes $(\mathrm{n}=2)$.

All the seventeen products were used for application evaluation either with a basecoat $(\mathrm{n}=11$, in cases where a same brand basecoat was available) or without a basecoat $(\mathrm{n}=17)$. Eleven of the products were used for removal evaluation either with a basecoat and a topcoat ( $\mathrm{n}=7$, in cases where a same brand basecoat and topcoat were available) or without any basecoat and topcoat $(n=11)$. Only products that could be removed with acetone were included in the removal evaluation. The coated version and uncoated version from the same sample were treated as independent samples.

Application and removal were evaluated as two separate processes with their distinct sensory attributes. When applying a nail polish product, the aesthetic characteristics, mainly visual and textural, but also aromatic characteristics of a nail polish would be valued, whereas, when removing polish, the ease with which the nail polish can be removed would be valued.

All nail polishes were maintained in their original bottles wrapped with red masking tape to blind specific product information. A three-digit code was assigned to each product for tracking purposes. Products were stored at room temperature $\left(25 \pm 1^{\circ} \mathrm{C}\right)$ and protected from sunlight.

A total of 12 identical artificial hands (Premier Soft Hands, China) were used as carriers for artificial nails (Brentwood Beauty laboratories International, Inc., Dallas, TX, USA). The nails were adhered to the hands using nail glue (Professional Nail Glue, American International Industries, Los Angeles, CA, USA). Nail polishes were evaluated on the artificial nails other 
than on real nails to provide consistency among different panelists, and because of ease of cleaning and safety concerns for too frequent application and removal of polish for panelists actual nails.

\section{Test Preparation}

\section{Application}

The preparation work for application studies was done one day before the test day. Artificial nails were renewed daily. A label with a three digit code was placed on each finger of the artificial hand to indicate the product. If a basecoat was used, it was applied by a technician in three strokes - one in the middle, then one to the left, and finally one stroke to the right side of the artificial nail - before the panelists coated the nail with polish. Furthermore, if a curing process was required, the basecoat would be cured immediately under either a UV light or a LED light as required by the sample manufacturer (Table I). Prepared hands and nails were stored overnight at ambient temperature $\left(25 \pm 1^{\circ} \mathrm{C}\right)$ at approximately $55 \%$ relative humidity.

\section{Removal}

Preparation work for removal studies also was done one day before the test day. In case a basecoat layer was needed, it was applied in three strokes (middle, left, right) and was allowed to dry for 5 min. If no basecoat was used, that step was skipped. The first coat of sample in three strokes was applied and was allowed to dry for 5 min. The second coat of sample was applied in three strokes and was allowed to dry for 5 min. Finally, a topcoat was applied if required by the sampling design.

Acetone (Brentwood Beauty laboratories International, Inc., U.S.) poured on a cotton pad (Esthetician Services, Inc., Los Angeles, CA, USA) was used as the removal liquid for the nail 
polishes. The acetone used $(0.41 \mathrm{ml})$ was measured into $5 \mathrm{ml}$ brown glass bottles and supplied to each panelist for removal.

\section{Lexicon development}

A total of eight $1.5 \mathrm{~h}$ sessions were used for lexicon development. Five of the sessions were used for lexicon development for the application process and appearance and the other three sessions were for lexicon development for the removal process. For guidance, the panel initially was given lexicons that had been used for lipstick [18] and in proprietary studies of automotive paint finishes, but were encouraged to modify terminology and add to or remove terms to create an appropriate lexicon for nail polishes. Panelists used the attributes that were appropriate for nail polish from previous studies, and generated new attributes according to the features of nail polish. Definitions for the new attributes were then created by the panel, and references were developed by researchers in Sensory Analysis Center according to the panel's request. All the sessions took place in a noise and climate controlled room $\left(25 \pm 1^{\circ} \mathrm{C}\right.$ and $55 \%$ relative humidity). This procedure is similar to that used for other recent studies [18, 21, 22] and has been shown to be reasonably consistent among different panels [23].

\section{Lexicon validation}

A total of two days of $1.5 \mathrm{~h}$ orientation and fourteen days for $1.5 \mathrm{~h}$ individual evaluation sessions were conducted. During orientation, several mock evaluations, followed by comparison of scores, were performed for calibration among panelists. Evaluation techniques (Table II) were developed so that panelists could use the same procedures evaluating products. An incomplete block design was used for evaluation of application and removal attributes of the samples. Six highly trained panelists participated in this study. Three replications were conducted for each sample. No discussion was allowed during evaluation. In the middle of each evaluation session, 
there was a 10 min break. Panelists used a scale, from 0 (extremely low) to 15 (extremely high) with 0.5 increments to evaluate the intensity of attributes. These evaluation procedures are typical and have been used for other sensory studies. [18, 23]

\section{Data analysis}

The Sensory Analysis Center uses Compusense at-hand (Compusense Inc., Guelph, ON, Canada) for data collection. Analysis of Variance (ANOVA) was performed using the Glimmix procedure in SAS ${ }^{\circledR}$ statistical software (Version 9.3, SAS Institute Inc., Cary, NC) to identify significant differences $(\mathrm{p}<0.05)$ among nail polishes for each attribute. If significant differences were noted, the LSMeans procedure was used to determine specific differences among products. Pearson's correlation coefficients were calculated to explore the correlations between each pair of descriptive attributes using SAS®.

Principal Component Analysis (PCA) was conducted to detect the relationships among attributes and samples (The Unscrambler X version 10.2, Camo Software AS, Oslo, Norway). According to Abdi and Williams [24], PCA is a multivariate technique that analyzes a data table in which observations are described by several inter-correlated quantitative dependent variables. Its goal is to extract the important information from the table, to represent it as a set of new orthogonal variables called principal components, and to display the pattern of similarity of the observations and of the variables as points in maps. 


\section{Results and Discussion}

\section{Lexicon Development}

Application and appearance of nail polish

Several attributes such as smoothness, spreadability, initial-drag, color intensity, shininess, wetappearance, glittery, pearl-like, coverage, and opacity used in a lip product study conducted by Dooley et al. [18] were considered applicable for this nail polish study. Definitions and references for these attributes were modified for nail polish. For example, ChapStick ${ }^{\circledR}$ classic (Pfizer, Madison, NJ, USA) was not appropriate as a high intensity (12.0 on a scale from 0 to 15.0) reference for initial-drag. Thus, the panel assigned a lower score-6.0 to the Chapstick, and added two new references with higher intensities for initial-drag. These were sandpaper (fine) $=10.0$ and sandpaper $($ rough) $=14.0$ (Table III).

Some of the sensory properties developed by the panel and related to the liquid characteristics of the nail polish were runny, fatty-edge, blisters, pinholes and brushlines. A flake-protrusion attribute was developed to characterize the flake configuration in nail polishes F1 and F2. Five aromatics attributes developed for the application study were petroleum-like, acetone, nutty, woody, and fruity-floral. The standard references for aroma were either specific

products or chemical solutions. For example, Vaseline ${ }^{\circledR}$ (Unilever, Trumbull, CT, USA) was used as the reference for attribute petroleum-like, and 2-acetyl-pyridine (100 ppm in water) solution was used as the reference for attribute nutty.

Appearance attribute references, except runny, wet-appearance and shininess, were all pictures or photographs. Some of them (color intensity, glittery, pearl-like, opacity) were adopted from a lip product study [18], while others (fatty-edge, blisters, pinholes, coverage, 
brushlines, flake-protrusion) were developed or modified by the panel. For example, the attribute fatty-edge was defined, and references were developed by painting with a brush at different application pressures using different amounts of paint until the appropriate levels of edge were developed. Then photographs of those standards were used as references during evaluation.

Removal of nail polish

Five attributes were evaluated in the removal of nail polish to characterize ease of removal and potential residues on nail surface. The ease of removal attributes included drag and number of strokes; and the potential residues attributes included shine, coverage, and color intensity. Each attribute was evaluated at up to 5 different time points: before evaluation, after one stroke with acetone-soaked cotton pad, after five more strokes, after another five strokes, and number of strokes necessary to completely clean the nail. In case the number of strokes was higher than 20, the panel would stop and evaluate the attributes in the last stage. The standard references used for removal evaluation were the same as the ones used in the application evaluation.

\section{Lexicon Validation}

Application and appearance

Results (Table IV) suggested that the lexicon of 21 application attributes can separate the 28 nail polish samples (17 non-basecoat products +11 basecoat products) effectively. Significant differences were detected in 20 out of 21 sensory attributes. Blisters was the only attribute where no significant differences among samples were found.

Flake-protrusion and pearl-like were attributes that were detected in only a limited number of samples. The flake-protrusion attribute separated flake-containing products and non- 
flake products. Pearl-like was scored around 1.5 for two regular samples and one water-based sample, whereas it was scored a 0 or close to 0 in all the other samples. Pearlescent may not be a major characteristic of this set of sample, but it is still relevant to the sensory property of nail polish. In addition, although glittery separated samples into six groups, more than half of the samples scored zero for the attribute glittery because those samples did not have that characteristic. The use of attributes such as pearl-like and glittery would depend on the objectives and samples included in the study.

The texture and appearance attributes in the lexicon were able to discern differences among and within the four nail polish categories - regular, flake-containing, gel and water-based. Several attributes (smoothness, spreadability, initial-drag, wet-appearance and coverage) could separate flake-containing samples and water-based samples from regular and gel samples. For example, flake-containing samples BF2, F1 and F2 and water-based samples W1 and W2 were lowest in smoothness. Two attributes (color intensity and runny) were useful in separating water-based products from the other samples; water-based samples were low in intensity for both attributes. Shininess separated gel nail polish from the other samples, because all the gel nail polish samples (BG1, BG2, BG3, BG4, G1, G2, G3 and G4) exhibited shininess properties high in intensity. The brushlines and pinholes attributes separated samples within the gel category. Gel nail polish samples BG3 and G3 were scored highest in intensity of brushlines and pinholes. Among the aroma attributes, acetone separated regular samples from gel-type and water-based samples. The fruity-floral aroma addition to samples G2, W1 and W2 could cover up the acetone or other notes that could be present.

Principal Component Analysis (PCA) of the 21 application attributes helped visualize the differences among the four product categories (Fig. 1). PC1 accounted for 35\% of the variation, 
and it seemed to differentiate among samples according to most of the initial texture (such as smoothnesss and initial drag) and initial appearance (such as wet appearance and brushlines) attributes. PC2 accounted for $24 \%$ of the variation, and it seemed to differentiate samples according to all the aroma attributes, including acetone, nutty, petroleum-like, woody and fruityfloral.

A basecoat did not seem to affect application properties of a nail polish, because most samples with a basecoat positioned close to their non-basecoat version in the PCA map. A basecoat is a common nail care product, usually transparent, fills in irregularities of the nail plate and provides a uniform, neutral color as the starting point for the pigmented nail polish [25]. For example, BR2 was shown at almost the same place as R2. This was also true for flakecontaining products and gel-type products. This suggested that a basecoat may not affect the sensory properties, although it may affect the physical properties, such as the staying power to resist chipping of nail polish. The gel nail polish products were more associated with most of the aroma attributes including woody, nutty, petroleum-like and fruity-floral, but they were low in acetone and runny.

The two water-based nail polish samples (W1 and W2) were grouped together, but both were located far from the other samples. This suggested that W1 and W2 were similar in initial texture, initial appearance and aroma (PC1 and PC2) characteristics, but quite different from the others. The binder/cross-linker of water-based nail polishes can be dispersed in water and this may keep the volatile organic content low [26]. These two samples had pronounced fruity-floral, petroleum-like, and nutty aromatics.

All three flake-containing samples (F1, F2 and BF2) were grouped together, but separated from all the other samples. These samples had pronounced flake-protrusion, glittery 
and initial-drag attributes, but exhibited low smoothness, spreadability, wet-appearance, coverage, shininess, and opacity intensities. 


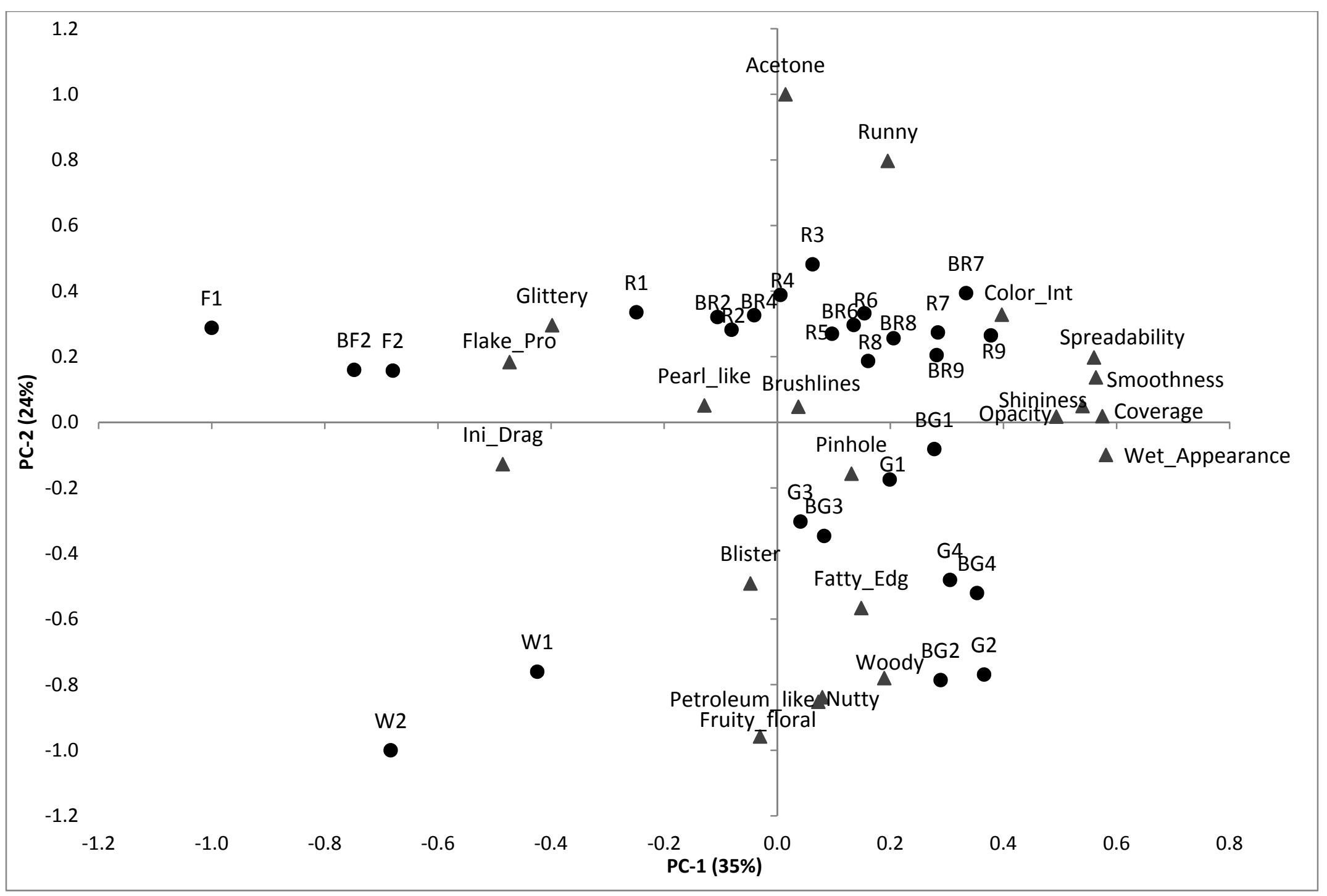

Figure 1 Principal Component Analysis of nail polish samples based on 21 application attributes.

$$
(\boldsymbol{\Delta} \text {, attributes; } \bullet \text {, products) }
$$


The results from Pearson's Correlation Coefficient analysis showed that spreadability, smoothness, shininess, opacity, coverage, and wet-appearance were positively correlated with each other, which suggests that although they measure different characteristics, they are all related similarly to underlying formulation differences in products. These attributes were negatively correlated with both initial-drag and flake-protrusion. It was found that opacity was positively related to color intensity $(\mathrm{r}=0.74)$. Runny was negatively related to initial-drag ( $\mathrm{r}=-$ 0.51). The initial drag could be caused by the viscosity of the nail polish sample, and viscosity could negatively associate with the runny property. Both initial-drag and glittery were positively correlated with flake-protrusion $(r=0.77, r=0.56)$. Flakes may increase the resistance to application, resulting in the amount of pressure required to apply the sample (initial-drag) to increase.

\section{Removal}

According to the average intensity values (Table V), before any treatment (stage 0), the intensities of shine and color intensity were consistent with the application attributes shininess and color intensity. Coverage was evaluated as 15.0 in intensity in all samples other than F1. Similar findings were detected during application as sample F1 was evaluated low in coverage attribute intensity (Table IV). According to these results sample F1 exhibited characteristics in application that were likely to result from product formulation rather than application procedures.

In stage 1 of removal, the intensities of shine, coverage, color intensity, and drag of regular samples decreased significantly (Table V). However, the intensities of those attributes in flake-containing samples did not follow the same pattern. This suggested that the flakes in nail polish increased the difficulty to remove nail polish. In addition, in most of the regular samples (R2, R6, R7 and R8), the non-basecoat version was found significantly lower than the basecoat 
version in coverage during removal. In half of the regular samples (R6, R7 and R8), the nonbasecoat version was found significant lower than the basecoat version in drag. This suggests that adding basecoat helps the nail polish to be more resistant to removal, a property that would help in the long lasting, anti-chip characteristics of some nail polishes.

Furthermore, for coverage, color intensity and drag attributes in stage 2, all the nonbasecoat regular samples had lower scores than their basecoat version (other than samples R9 and R4) meaning that samples that did not have a basecoat were more easier to remove. This could support the claim for some nail polish products that a basecoat could help nail polish last longer on nails.

In stage 3 , all the samples had a score of " 0 " or close to " 0 " for coverage and color intensity apart from samples F1, F2, BF2, and BR9. The flake-containing samples were still high in intensity for all the three attributes at this stage. Within the regular category, the nonbasecoat samples were not significantly different from their basecoat version in coverage and color intensity, except samples R8 and R9. However, for the attribute drag, except for sample R4, all regular samples had a lower score in their non-basecoat than their basecoat version.

In stage 4, only three flake-containing samples (F1, F2 and BF2) had obvious scores on the attributes evaluated. For the other samples, the scores in coverage, color intensity, and drag attributes were "0" or close to " 0 " indicating complete removal by this point.

In the PCA map relating to removal of nail polishes (Fig. 2), PC1 accounted for $71 \%$ of the variation, and seemed to be highly related to flake-protrusion. PC2 accounted for $14 \%$ of the variation, and was associated with the intensity of nail polish residuals. 
Unlike the PCA map relating to application of nail polishes, samples in the removal PCA map were different between the basecoat version and a non-basecoat version. For example, BR2 and R2, which positioned closely on the application PCA map, were not located closely on the removal PCA map, and this was further confirmed by the differences in average color intensity and drag attribute values (Table V). However, the flake-containing product was an exception since BF2 was still close to F2 in the removal PCA map. This is likely to show that the flakecontaining characteristic affected the sensory removal properties more than the basecoat/nonbasecoat application. The samples with flakes were highly separated from the other samples using this lexicon.

A basecoat seemed to be a factor that may add wear resistance, because the basecoat version of a nail polish usually had higher coverage, drag and color intensity scores than the nonbasecoat version during removal. Non-basecoat nail polish products could be completely removed with fewer strokes than their basecoat versions before the third stage of removal. Sample F1, F2 and BF2, which contained flakes, seemed to be more difficult to remove from nails than regular samples. 


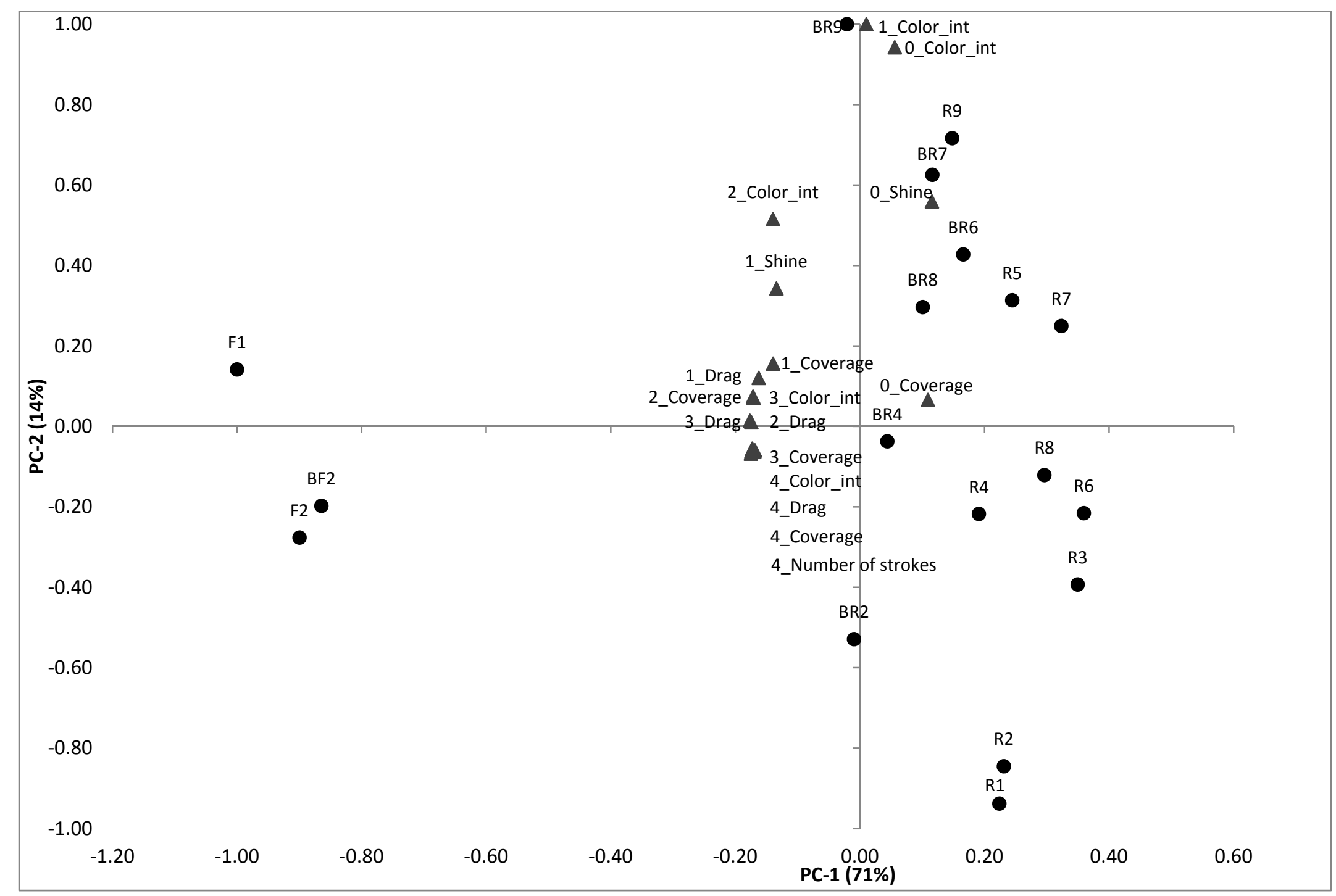

Figure 2 Principal Component Analysis of nail polish samples based on 5 removal attributes in 5 stages (0-4).

( $\boldsymbol{\Delta}$, attributes; $\boldsymbol{\bullet}$, products; the number before the attribute indicated the time point that attribute was evaluated. 


\section{Conclusions}

This study developed a lexicon for understanding the sensory properties of the application and removal of nail polish. For application, twenty-one attributes, which included three initial texture attributes, thirteen initial appearance attributes and five aroma attributes, were noted. For removal, five attributes appeared to be critical to measure as shown over five stages of removal.

The lexicons were validated by a trained panel using descriptive analysis on seventeen nail polish products. These products were from four categories - regular, flake-containing, water-based and gel. Some of the samples were evaluated both with a basecoat and without a basecoat. The results from ANOVA and PCA showed that the attributes in the lexicon separated the different product categories. In addition it was found that basecoat has a bigger effect on removal properties of a nail polish sample than on application properties.

This study provides scientists interested in nail polish an additional tool to describe nail polishes and better understand differences among them. Also, it could provide those who already use descriptive analysis on nail polish more information about the product category. In the future, further studies could look at relating descriptive data from this study to physical and consumer data to provide more comprehensive understanding on nail polish.

\section{Source of funding}

This study was funded from the Sensory Analysis Center resources. 


\section{References}

1. Sun, F. Nail Polish Sales Hit Record \$768 Million in U.S. Available at: http://style.time.com/2013/01/28/nail-polish-sales-hit-record-768-million-in-u-s/. Accessed 9/25, 2013.

2. Wischhover, C. American Women Spent $\$ 768$ Million on Nail Polish in 2012. Available at http://fashionista.com/2013/01/women-spent-768-million-on-nail-polish-in-2012/. Accessed 10/30, 2013

3. Schlossman, M.L. Techniques for evaluation of nail enamel. J. Soc. Cosmet. Chem.32, 43-52 (1981).

4. Schlossman, M.L. and Wimmer, E. Advances in nail enamel technology. J. Soc. Cosmet. Chem.43, 331-337 (1993).

5. Koch, D., and Rassek, R. Water-based nail polish. US patent number: 5,120,529. Date of patent: June 9, 1992.

6. Mui, R., Lee, C.T., Candia, T., Joyce, J. and Wimmer, E. O17. The development of 'time release’ nail enamels. Int. J. Cosmetic Sci.22, 121-131 (2000).

7. Bauman, M., and Nolan, J. Creation and implantation of an artificial nail for the treatment of deformed or missing nails. US patent number: 8,641,761. Date of patent: February 4, 2014.

8. Polanish, E. Foam applicators to apply cosmetics or nail polish. US patent number: 8,584,686. Date of patent: November 19, 2013.

9. Gueret, J-L. Packaging and applicator device. US patent application 20040202502. Application date: October 14, 2004.

10. Vu, T., and Schoon, D.D. Removable multilayer nail coating system and methods therefore. US patent number: 8,541,482. Date of patent: September 24, 2013.

11. Steffier, L.W. UV-curable nail coating formulations based on renewable polyols. US patent number: 8,574,558. Date of patent: November 5, 2013.

12. Weber. S.M., Lee, C.J., and Raouf, M. Nail strips having a crosslinked polymer top coat. US patent number: 8,596,164. Date of patent: November 19, 2013.

13. Parente, M.E., Gambaro, A. and Ares, G. Sensory characterization of emollients. J. Sens. Stud. 23, 149-161 (2008). 
14. Barkat, S., Thomas-Danguin, T., Bensafi, M., Rouby, C., and Sicard, G. Odor and color of cosmetic products: correlations between subjective judgement and autonomous nervous system response. Int. J. Cosmetic Sci.25, 273-283 (2003).

15. Bacle, I., Meges, S., Lauze, C., Macleod, P. and Dupuy, P. Sensory analysis of four medical spa spring waters containing various mineral concentrations. Int. J. Dermatol.38, 784-786 (1999).

16. MacLennan, A., Shaw, R., and Jones, L. Comparative assessment of talc slip using a sensory analysis technique. Int. J. Cosmetic Sci.14, 75-81 (1992).

17. Wortel, V.A.L., and Wiechers, J.W. Skin sensory performance of individual personal care ingredients and marketed personal care products. Food Qual Pref. 11, 121-127 (2000).

18. Dooley, L. M., Adhikari, K. and Chambers, E. IV. A general lexicon for sensory analysis of texture and appearance of lip products. J. Sens. Stud.24, 581-600 (2009).

19. Yenket, R., Chambers, E. IV, and Gatewood, B.M. Color has little effect on perception of fabric handfeel tactile properties in cotton fabrics. J. Sens. Stud. 22, 336-352(2007).

20. Robinson, K.J., Chambers, E. IV, and Gatewood, B.M. Influence of pattern design, color, and fabric type on the hand characteristics of pigmented prints. Text Res. J. 67: 837-845 (1997).

21. Di Donfrancesco, B., Koppel, K. and Chambers, E. IV. An initial lexicon for sensory properties of dry dog food. J. Sens. Stud.27, 498-510 (2012).

22. Chambers, E. IV, Lee, J., Chun, S., and Miller, A. E. Development of a Lexicon for Commercially Available Cabbage (Baechu) Kimchi. J Sens Stud. 27, 511-518 (2012).

23. Cherdchu, P., Chambers, E. IV, and Suwonsichon, T. Sensory lexicon development using trained panelists in Thailand and the United States: soy sauce. J. Sens Stud. 28, 248-255 (2013).

24. Abdi, H., Williams, L. J. Principal component analysis. WIREs Comput Stat. 2, 433-459 (2010).

25. Iorizzo, M., Piraccini, B.M., and Tosti, A. Nail cosmetics in nail disorders. J. Cosmet. Dermatol. 6, 53-58 (2007).

26. Schlossman, M. Additives for water-based nail polish. J. Soc. Cosmet. Chem. 50, 105-109 (1999). 
Table I Nail polish samples and sampling plan.

\begin{tabular}{cllll}
\hline No. & Code $^{\mathrm{a}}$ & Category & Application & Removal \\
\hline 1 & F1 & Flake-containing & Yes & Yes \\
2 & F2 & Flake-containing & Yes & Yes \\
3 & R1 & Regular & Yes & Yes \\
4 & R2 & Regular & Yes & Yes \\
5 & R3 & Regular & Yes & Yes \\
6 & R4 & Regular & Yes & Yes \\
7 & R5 & Regular & Yes & Yes \\
8 & R6 & Regular & Yes & Yes \\
9 & R7 & Regular & Yes & Yes \\
10 & R8 & Regular & Yes & Yes \\
11 & R9 & Regular & Yes & Yes \\
12 & G1 & Gel & Yes & No \\
13 & G2 & Gel & Yes & No \\
14 & G3 & Gel & Yes & No \\
15 & G4 & Gel & Yes & No \\
16 & W1 & Water-based & Yes & No \\
17 & W2 & Water-based & Yes & No \\
18 & BF2 & Flake-containing/Basecoat/Topcoat ${ }^{c}$ & Yes & Yes \\
19 & BR2 & Regular/Basecoat/Topcoat & Yes & Yes \\
20 & BR4 & Regular/Basecoat/Topcoat & Yes & Yes \\
21 & BR6 & Regular/Basecoat/Topcoat & Yes & Yes \\
22 & BR7 & Regular/Basecoat/Topcoat & Yes & Yes \\
23 & BR8 & Regular/Basecoat/Topcoat & Yes & Yes \\
24 & BR9 & Regular/Basecoat/Topcoat & Yes & Yes \\
25 & BG1 & Gel/Basecoat & Yes_g & No \\
26 & BG2 & Gel/Basecoat & Yes_g & No \\
27 & BG3 & Gel/Basecoat & Yes_g & No \\
28 & BG4 & Gel/Basecoat & Yes_g & No \\
\hline & & & & \\
\hline
\end{tabular}

${ }^{\mathrm{a}}$ The letters in this column are short for the category information in the third column.

b "Yes_g” means the basecoats of the samples need to be cured.

c Topcoats were only used in removal evaluation. 
Table II Preparation and evaluation techniques used in application and removal of a nail polish product.

Preparation Procedures

If there is a basecoat, it should be applied to an artificial nail in three strokes (middle, left, right). If there is no basecoat, no further action need be done.

ธี The basecoat of BG1 need be cured under UV light . for 1minute; the basecoat of BG3 need be cured under a UV light for 2 min; whereas the basecoats of BG2 and BF4 need be cured under an LED light for 1min.

If there is a basecoat, it should be applied to an artificial nail in three strokes (middle, left, right). If there is no basecoat, skip this step and proceed to the second step directly.

Secondly, when the basecoat is dry (about 5 min later), apply the first coat of sample in three strikes.

Thirdly, 5 min later, apply the second coat of sample in three strikes.

\section{Finally, another 5 min later, apply the topcoat if the} sample is with a topcoat.

\section{Evaluation Procedures}

At first, invert the nail polish bottle several times in a frequency of once per second for twenty seconds.

Secondly, open bottle, and draw brush out against the inside of bottle to remove excess nail polish.

Thirdly, turn the brush over and apply on nail with the side of brush with the most polish.

Finally, touch brush to top of nail at cuticle; draw brush smoothly over nail to tip without brush stem touching the nail; use one nail for one drag, in the middle of the nail.

At first, evaluate the attributes shine, coverage and color intensity.

Secondly, Take applicator, dump acetone from vial in the center of applicator. Fold applicator from the center and apply applicator to polished nail surface, let sit for 5 seconds. Use 2 fingers on top of applicator and 1 below and pull applicator with firm pressure towards the tip of the nail, covering the while nail with applicator. Evaluate attributes shine, coverage, color intensity and drag.

Thirdly, take a new applicator, dump acetone from vial in the center of applicator, and fold applicator from the center. With firm pressure make 5 more strokes from top of nail to tip and evaluate coverage, color intensity and drag.

Fourthly, if necessary, take new applicator, dump acetone from vial in the center of applicator, and fold applicator from the center. With firm pressure make 5 more strokes from top of nail to tip and evaluate coverage, color intensity and drag.

Finally, if necessary, take new applicator, dump acetone from vial in the center of applicator, and fold applicator from the center. Count strokes to completely remove the product. If the count is higher than 20 , stop and evaluate number of strokes, coverage, color intensity and drag. 
Table III Definition and reference sheet used by panelists

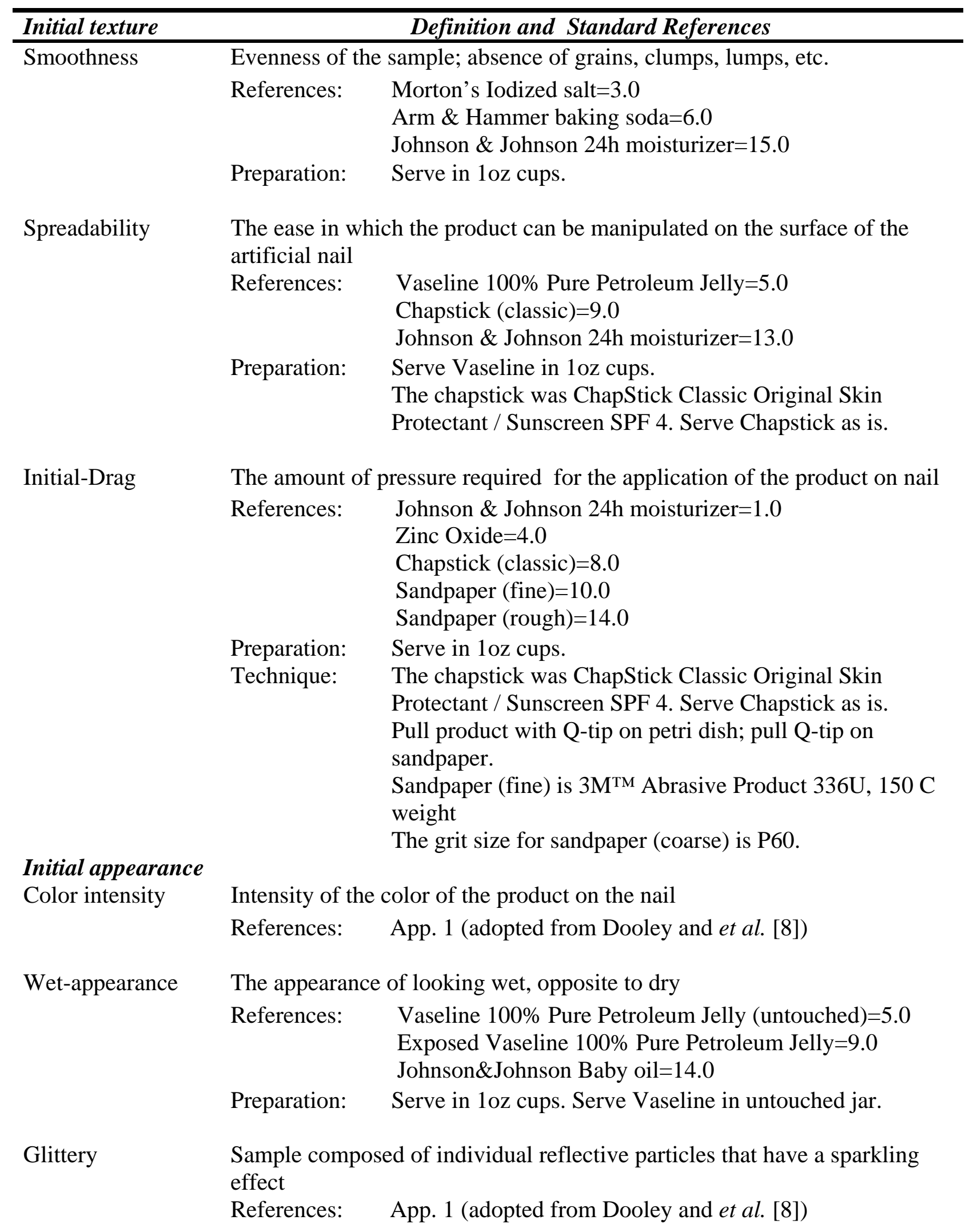


Pearl-like

A soft, reflective luster reminiscent of a pearl of mother-of-pearl; gives depth.

References: $\quad$ App. 1 (adopted from Dooley and et al. [8])

Opacity The degree of opaqueness of the product

References: $\quad$ App. 1 (adopted from Dooley and et al. [8])

Evaluate: Holding nail tips on top of the reference picture.

Runny Speed at which sample runs down when brushed against bottle neck

References: Johnson\&Johnson 24h moisturizer $=0.0$

Germ-X Hand Sanitizer= 7.5

Johnson\&Johnson Baby oil=15.0

Preparation: Serve in 1 oz cups.

Technique: Tilt cups to observe the movement.

Shininess The amount of gloss or shine perceived on the surface of the product

References: $\quad$ Paintchip Matt (Flat) $=2.0$

Paintchip Satin $=4.0$

Paintchip Semi-gloss $=6.0$

Paintchip High Gloss $=8.0$

Super High Gloss $=13.0$

Preparation: The paint chip selected was Sherwin-Williams finish selection for interiors for color SW 6573 juneberry. Spray Krylon Crystal Clear Gloss Acrylic Spray Finish on a paint chip, such as WGR27 or WGR21, let dry, and apply $2^{\text {nd }}$ coat (Super high gloss).

Fatty-edge

A smooth continuous rounded thickening partly or completely bordering the sample

References: App. 1

Blisters

Pinholes

Coverage

Brushlines

Flake-protrusion
A tactile surface rounded protrusion, having impression of trapped air.

References: App. 1

A minute tactile surface perforation generally appearing randomly

References: App. 1

The amount of testing surface covered by the product

References: App. 1

Thin, continuous parallel elongations generally appearing in number, resembling bristle drag on a soft surface

References: App. 1

A breaking away and an eruption of a metallic flake(s)

References: App. 1 


\section{Aroma}

Petroleum-like

Acetone

Nutty

Woody

Fruity-Floral
A specific chemical aromatic associated with crude oil and it's refined products that have heavy oil characteristics.

References: $\quad$ Vaseline 100\% Pure Petroleum Jelly=4.5

Preparation: $\quad$ Weigh $1 \mathrm{~g}$ of Vaseline in medium snifter, cover.

Aroma characteristic of ketones specifically acetone

References: $\quad$ Acetone $=5.0$

Preparation: Put 1 drop of acetone in medium snifter on cotton ball, cover.

A non-specific nut-like aromatic note that was a combination of several different nuts such as pecans, hazelnuts, peanuts, etc., unless otherwise described.

References: $\quad$ 2-acetyl-pyridine (100ppm dip strips)=7.0(a)

Put 1 drop in medium snifter on cotton ball, cover.

The sweet, brown, musty, flat, dark, dry aromatics associated with the bark of a tree.

References: $\quad$ Oil Cedarwood(Sigma, dip strips)=5.5(a)

Put 1 drop in medium snifter on cotton ball, cover.

A sweet, floral aromatic blend, reminiscent of a variety of fruits such as cherry, peach, pear, etc.

References: $\quad$ trans-2-hexenal (10000ppm, dip strip)=5.0(a)

Put 1 drop in medium snifter on cotton ball, cover. 
Table IV Results from ANOVA and T grouping in application evaluation based on each attribute.

Part 1.

\begin{tabular}{|c|c|c|c|c|c|c|c|}
\hline & Smoothness & Spreadability & Ini_Drag & Color_Int & Wet_Appearance & Glittery & Pearl_like \\
\hline $\mathrm{BF} 2$ & $9.86^{\mathrm{hi}} *$ & $9.61^{\mathrm{fg}}$ & $4.39^{\mathrm{a}}$ & $6.67^{\mathrm{jk}}$ & $7.39^{\mathrm{h}}$ & $11.69^{\mathrm{a}}$ & $0.00^{\mathrm{C}}$ \\
\hline BR2 & $12.83^{\text {cdefg }}$ & $12.11^{\text {bcde }}$ & $1.81^{\mathrm{efg}}$ & $5.92^{\mathrm{kl}}$ & $11.72^{\text {bcde }}$ & $9.83^{\mathrm{bc}}$ & $1.64^{\mathrm{a}}$ \\
\hline BR4 & $13.00^{\text {abcdefg }}$ & $11.61^{\text {de }}$ & $1.81^{\mathrm{efg}}$ & $7.69^{\text {ghi }}$ & $10.44^{\mathrm{ef}}$ & $6.56^{\mathrm{d}}$ & $0.00^{\mathrm{C}}$ \\
\hline BR6 & $12.92^{\text {abcdefg }}$ & $12.25^{\text {bcde }}$ & $2.08^{\text {cdefg }}$ & $8.33^{\text {cdefg }}$ & $11.61^{\text {bcde }}$ & $0.00^{f}$ & $0.06^{\mathrm{bc}}$ \\
\hline BR7 & $14.36^{\mathrm{a}}$ & $13.64^{\mathrm{a}}$ & $1.42^{\mathrm{g}}$ & $9.25^{\mathrm{bc}}$ & $12.56^{\mathrm{ab}}$ & $0.72^{f}$ & $0.00^{\mathrm{c}}$ \\
\hline BR8 & $13.58^{\text {abcde }}$ & $12.92^{\mathrm{abc}}$ & $1.81^{\mathrm{efg}}$ & $7.83^{\text {fghi }}$ & $12.28^{\mathrm{abc}}$ & $0.83^{\mathrm{f}}$ & $0.06^{\mathrm{bc}}$ \\
\hline BR9 & $13.22^{\text {abcdef }}$ & $12.33^{\text {bcde }}$ & $2.47^{\text {bcde }}$ & $10.92^{\mathrm{a}}$ & $12.64^{\mathrm{ab}}$ & $0.00^{f}$ & $0.00^{c}$ \\
\hline BG1 & $14.22^{\mathrm{a}}$ & $13.17^{\mathrm{ab}}$ & $1.81^{\mathrm{efg}}$ & $6.33^{\mathrm{jkl}}$ & $12.31^{\mathrm{abc}}$ & $0.00^{\mathrm{f}}$ & $0.00^{\mathrm{c}}$ \\
\hline BG2 & $13.81^{\mathrm{abcd}}$ & $12.64^{\mathrm{abcd}}$ & $1.92^{\mathrm{efg}}$ & $8.86^{\text {bcd }}$ & $12.61^{\mathrm{ab}}$ & $0.00^{\mathrm{f}}$ & $0.00^{\mathrm{C}}$ \\
\hline BG3 & $12.47^{\mathrm{efg}}$ & $11.28^{\mathrm{e}}$ & $2.67^{\mathrm{bc}}$ & $6.58^{\mathrm{jkl}}$ & $11.94^{\mathrm{abcd}}$ & $0.17^{\mathrm{f}}$ & $0.00^{\mathrm{C}}$ \\
\hline BG4 & $14.08^{\mathrm{ab}}$ & $12.50^{\mathrm{bcd}}$ & $1.94^{\mathrm{defg}}$ & $8.75^{\text {bcdef }}$ & $13.11^{\mathrm{a}}$ & $0.00^{f}$ & $0.00^{\mathrm{C}}$ \\
\hline F1 & $10.17^{\mathrm{h}}$ & $9.44^{\mathrm{fg}}$ & $4.33^{\mathrm{a}}$ & $6.89^{\mathrm{ij}}$ & $3.22^{\mathrm{i}}$ & $4.81^{\mathrm{e}}$ & $0.00^{\mathrm{C}}$ \\
\hline F2 & $8.94^{\mathrm{i}}$ & $9.97^{f}$ & $2.61^{\mathrm{bcd}}$ & $6.53^{\mathrm{jkl}}$ & $6.78^{\mathrm{h}}$ & $11.06^{\mathrm{ab}}$ & $0.00^{c}$ \\
\hline $\mathrm{R} 1$ & $12.72^{\text {edfg }}$ & $11.64^{\mathrm{de}}$ & $1.89^{\mathrm{efg}}$ & $5.92^{\mathrm{kl}}$ & $9.42^{\mathrm{fg}}$ & $9.33^{c}$ & $0.53^{b}$ \\
\hline R2 & $13.36^{\text {abcdef }}$ & $12.44^{\mathrm{bcd}}$ & $1.61^{\mathrm{g}}$ & $5.64^{1}$ & $10.83^{\mathrm{de}}$ & $9.78^{\mathrm{bc}}$ & $1.44^{\mathrm{a}}$ \\
\hline R3 & $13.56^{\text {abcde }}$ & $12.50^{\mathrm{bcd}}$ & $1.67^{\mathrm{fg}}$ & $6.94^{\text {hij }}$ & $11.53^{\text {bcde }}$ & $0.00^{f}$ & $0.25^{\mathrm{bc}}$ \\
\hline R4 & $13.67^{\text {abcde }}$ & $12.42^{\mathrm{bcd}}$ & $1.67^{\mathrm{fg}}$ & $7.86^{\mathrm{efgh}}$ & $11.17^{\text {cde }}$ & $6.83^{\mathrm{d}}$ & $0.33^{\mathrm{bc}}$ \\
\hline R5 & $13.25^{\text {abcdef }}$ & $12.00^{\text {cde }}$ & $1.89^{\mathrm{efg}}$ & $7.92^{\text {defg }}$ & $11.83^{\mathrm{abcd}}$ & $0.28^{f}$ & $0.00^{c}$ \\
\hline R6 & $13.47^{\text {abcde }}$ & $12.53^{\mathrm{abcd}}$ & $1.75^{\mathrm{fg}}$ & $9.06^{\mathrm{bc}}$ & $11.17^{\text {cde }}$ & $0.00^{\mathrm{f}}$ & $0.11^{\mathrm{bc}}$ \\
\hline R7 & $14.31^{\mathrm{a}}$ & $13.11^{\mathrm{abc}}$ & $1.81^{\mathrm{efg}}$ & $9.47^{\mathrm{b}}$ & $11.83^{\mathrm{abcd}}$ & $0.00^{\mathrm{f}}$ & $0.00^{c}$ \\
\hline R8 & $13.67^{\text {abcde }}$ & $12.83^{\mathrm{abc}}$ & $1.72^{\mathrm{fg}}$ & $7.97^{\mathrm{defg}}$ & $11.86^{\mathrm{abcd}}$ & $0.00^{f}$ & $0.00^{c}$ \\
\hline R9 & $13.97^{\mathrm{abc}}$ & $13.17^{\mathrm{ab}}$ & $1.83^{\mathrm{efg}}$ & $10.94^{\mathrm{a}}$ & $12.31^{\mathrm{abc}}$ & $0.00^{f}$ & $0.00^{\mathrm{C}}$ \\
\hline G1 & $13.94^{\mathrm{abc}}$ & $12.53^{\mathrm{abcd}}$ & $1.83^{\mathrm{efg}}$ & $6.06^{\mathrm{jkl}}$ & $12.67^{\mathrm{ab}}$ & $0.00^{f}$ & $0.00^{c}$ \\
\hline G2 & $13.97^{\mathrm{abc}}$ & $12.86^{\mathrm{abc}}$ & $1.61^{\mathrm{g}}$ & $9.22^{\mathrm{bc}}$ & $12.75^{\mathrm{ab}}$ & $0.00^{f}$ & $0.00^{c}$ \\
\hline G3 & $12.22^{\mathrm{fg}}$ & $11.61^{\text {de }}$ & $2.31^{\text {cdef }}$ & $6.44^{\mathrm{jkl}}$ & $12.22^{\mathrm{abc}}$ & $0.00^{\mathrm{f}}$ & $0.00^{c}$ \\
\hline G4 & $13.67^{\text {abcde }}$ & $12.78^{\mathrm{abc}}$ & $1.92^{\mathrm{efg}}$ & $8.81^{\text {bcde }}$ & $12.14^{\mathrm{abcd}}$ & $0.00^{\mathrm{f}}$ & $0.00^{\mathrm{C}}$ \\
\hline W1 & $12.00^{\mathrm{g}}$ & $11.64^{\text {de }}$ & $2.31^{\text {cdef }}$ & $3.28^{\mathrm{m}}$ & $9.44^{\mathrm{fg}}$ & $7.03^{\mathrm{d}}$ & $1.44^{\mathrm{a}}$ \\
\hline W2 & $9.56^{\mathrm{hi}}$ & $8.83^{\mathrm{g}}$ & $3.14^{b}$ & $2.78^{\mathrm{m}}$ & $8.11^{\text {gh }}$ & $0.00^{\mathrm{f}}$ & $0.06^{\mathrm{bc}}$ \\
\hline
\end{tabular}

* Sample means with the same letter in a column are not significantly different $(\mathrm{P}<0.05)$. 
Table IV Part 2.

\begin{tabular}{|c|c|c|c|c|c|c|c|}
\hline & Opacity & Runny & Shininess & Fatty_Edg & Blisters** & Pinholes & Coverage \\
\hline $\mathrm{BF} 2$ & $9.39^{\text {fghij }}$ & $9.14^{\text {fghij }}$ & $8.53^{\mathrm{i}}$ & $3.44^{\text {cdefghi }}$ & $0.00^{\mathrm{b}}$ & $0.00^{f}$ & $8.36^{\mathrm{lm}}$ \\
\hline BR2 & $8.06^{\mathrm{j}}$ & $10.64^{\mathrm{abc}}$ & $11.92^{\text {bcde }}$ & $4.17^{\text {bcdefgh }}$ & $0.00^{\mathrm{b}}$ & $0.08^{f}$ & $9.72^{\mathrm{ijk}}$ \\
\hline BR4 & $8.72^{\text {hij }}$ & $10.00^{\text {bcdef }}$ & $11.67^{\mathrm{de}}$ & $3.22^{\text {cdefghi }}$ & $0.00^{\mathrm{b}}$ & $1.11^{\text {bcde }}$ & $10.56^{\text {fghij }}$ \\
\hline BR6 & $10.17^{\text {defg }}$ & $10.25^{\text {bcde }}$ & $12.36^{\mathrm{abcd}}$ & $2.22^{\text {hi }}$ & $0.00^{\mathrm{b}}$ & $1.28^{\mathrm{bcd}}$ & $11.00^{\text {defghi }}$ \\
\hline BR7 & $11.22^{\mathrm{bcd}}$ & $9.75^{\text {cdefgh }}$ & $12.17^{\text {abcde }}$ & $3.00^{\text {defghi }}$ & $0.00^{\mathrm{b}}$ & $0.94^{\text {bcdef }}$ & $12.56^{\mathrm{ab}}$ \\
\hline BR8 & $9.47^{\text {fghi }}$ & $10.14^{\text {bcde }}$ & $12.61^{\mathrm{abcd}}$ & $4.89^{\mathrm{bcd}}$ & $0.08^{\mathrm{b}}$ & $1.31^{\mathrm{bcd}}$ & $11.44^{\text {bcdefg }}$ \\
\hline BR9 & $12.89^{\mathrm{a}}$ & $9.31^{\text {efghij }}$ & $12.56^{\mathrm{abcd}}$ & $4.17^{\text {bcdefgh }}$ & $0.11^{\mathrm{b}}$ & $1.22^{\mathrm{bcd}}$ & $12.33^{\mathrm{abc}}$ \\
\hline BG1 & $11.61^{\mathrm{abc}}$ & $8.83^{\text {hij }}$ & $13.11^{\mathrm{a}}$ & $2.39^{\text {ghi }}$ & $0.00^{\mathrm{b}}$ & $0.36^{\text {cdef }}$ & $12.97^{\mathrm{a}}$ \\
\hline BG2 & $10.67^{\text {cdef }}$ & $8.78^{\mathrm{ij}}$ & $13.03^{\mathrm{a}}$ & $4.33^{\text {bcdefg }}$ & $0.11^{\mathrm{b}}$ & $0.22^{\mathrm{ef}}$ & $11.61^{\text {bcdef }}$ \\
\hline BG3 & $9.86^{\text {efgh }}$ & $9.17^{\text {fghij }}$ & $12.67^{\mathrm{abcd}}$ & $4.17^{\text {bcdefgh }}$ & $0.22^{\mathrm{ab}}$ & $3.75^{\mathrm{a}}$ & $11.17^{\text {cdefgh }}$ \\
\hline BG4 & $11.22^{\mathrm{bcd}}$ & $9.36^{\text {efghi }}$ & $13.22^{\mathrm{a}}$ & $5.44^{\mathrm{b}}$ & $0.00^{\mathrm{b}}$ & $0.39^{\text {cdef }}$ & $12.39^{\mathrm{abc}}$ \\
\hline $\mathrm{F} 1$ & $4.50^{1}$ & $8.39^{j}$ & $10.17^{\mathrm{fg}}$ & $0.11^{j}$ & $0.00^{\mathrm{b}}$ & $0.00^{f}$ & $4.94^{n}$ \\
\hline F2 & $8.81^{\mathrm{hij}}$ & $9.39^{\text {efghi }}$ & $9.25^{\text {ghi }}$ & $2.39^{\text {ghi }}$ & $0.00^{\mathrm{b}}$ & $0.00^{f}$ & $8.64^{\mathrm{klm}}$ \\
\hline $\mathrm{R} 1$ & $8.08^{\mathrm{j}}$ & $9.86^{\text {bcdef }}$ & $10.00^{\text {gh }}$ & $2.06^{\mathrm{ij}}$ & $0.00^{\mathrm{b}}$ & $0.11^{f}$ & $9.50^{\mathrm{jkl}}$ \\
\hline R2 & $8.11^{\mathrm{j}}$ & $10.72^{\mathrm{ab}}$ & $11.17^{\mathrm{ef}}$ & $3.44^{\text {cdefghi }}$ & $0.00^{\mathrm{b}}$ & $0.06^{f}$ & $10.78^{\text {efghij }}$ \\
\hline R3 & $8.47^{\mathrm{ij}}$ & $11.22^{\mathrm{a}}$ & $11.72^{\text {cde }}$ & $2.56^{\text {fghi }}$ & $0.00^{\mathrm{b}}$ & $0.17^{\mathrm{ef}}$ & $9.86^{\mathrm{hijk}}$ \\
\hline R4 & $8.47^{\mathrm{ij}}$ & $10.44^{\mathrm{abcd}}$ & $11.19^{\mathrm{ef}}$ & $4.33^{\text {bcdefg }}$ & $0.00^{\mathrm{b}}$ & $0.61^{\text {cdef }}$ & $10.08^{h i j}$ \\
\hline R5 & $8.58^{\text {hij }}$ & $10.42^{\mathrm{abcd}}$ & $12.50^{\mathrm{abcd}}$ & $4.39^{\text {bcdef }}$ & $0.00^{\mathrm{b}}$ & $1.14^{\text {bcde }}$ & $10.19^{\text {ghij }}$ \\
\hline R6 & $10.36^{\text {cdefg }}$ & $9.97^{\text {bcdef }}$ & $11.14^{\mathrm{ef}}$ & $3.44^{\text {cdefghi }}$ & $0.00^{\mathrm{b}}$ & $0.11^{f}$ & $11.97^{\text {abcde }}$ \\
\hline R7 & $11.36^{\mathrm{bcd}}$ & $9.56^{\text {defghi }}$ & $12.28^{\mathrm{abcd}}$ & $2.56^{\text {fghi }}$ & $0.00^{\mathrm{b}}$ & $0.61^{\text {cdef }}$ & $12.17^{\mathrm{abcd}}$ \\
\hline R8 & $9.14^{\text {ghij }}$ & $9.81^{\text {bcdefg }}$ & $12.56^{\mathrm{abcd}}$ & $4.67^{\text {bcde }}$ & $0.28^{\mathrm{ab}}$ & $0.61^{\text {cdef }}$ & $10.86^{\text {edfghi }}$ \\
\hline R9 & $12.19^{\mathrm{ab}}$ & $9.89^{\text {bcdef }}$ & $13.06^{\mathrm{a}}$ & $4.06^{\text {bcdefgh }}$ & $0.00^{\mathrm{b}}$ & $0.33^{\mathrm{def}}$ & $12.61^{\mathrm{ab}}$ \\
\hline G1 & $10.33^{\text {cdefg }}$ & $8.86^{\text {ghij }}$ & $12.94^{\mathrm{ab}}$ & $3.17^{\text {cdefghi }}$ & $0.11^{\mathrm{b}}$ & $0.50^{\text {cdef }}$ & $12.17^{\mathrm{abcd}}$ \\
\hline G2 & $11.06^{\text {bcde }}$ & $8.89^{\text {ghij }}$ & $13.17^{\mathrm{a}}$ & $5.11^{\mathrm{bc}}$ & $0.00^{\mathrm{b}}$ & $0.33^{\mathrm{def}}$ & $12.14^{\mathrm{abcd}}$ \\
\hline G3 & $9.47^{\text {fghi }}$ & $9.42^{\text {efghi }}$ & $12.75^{\mathrm{abc}}$ & $3.94^{\text {bcdefghi }}$ & $0.50^{\mathrm{a}}$ & $1.78^{\mathrm{b}}$ & $10.08^{\text {hij }}$ \\
\hline G4 & $10.47^{\text {cdefg }}$ & $8.67^{\mathrm{ij}}$ & $13.22^{\mathrm{a}}$ & $4.56^{\text {bcde }}$ & $0.00^{\mathrm{b}}$ & $0.58^{\text {cdef }}$ & $12.03^{\text {abcde }}$ \\
\hline W1 & $6.50^{\mathrm{k}}$ & $8.67^{\mathrm{ij}}$ & $9.08^{\mathrm{hi}}$ & $2.83^{\text {efghi }}$ & $0.22^{\mathrm{ab}}$ & $0.00^{f}$ & $7.78^{\mathrm{m}}$ \\
\hline W2 & $6.22^{\mathrm{k}}$ & $7.08^{\mathrm{k}}$ & $7.44^{\mathrm{j}}$ & $8.00^{\mathrm{a}}$ & $0.28^{\mathrm{ab}}$ & $1.33^{b c}$ & $7.61^{\mathrm{m}}$ \\
\hline
\end{tabular}

**B Blisters is the only attribute that was not significantly different among all the samples. $(\mathrm{P}<0.05)$ 
Table IV Part 3.

\begin{tabular}{|c|c|c|c|c|c|c|c|}
\hline & Brushlines & Flake_Pro & Petroleum_like & Acetone & Nutty & Woody & Fruity_floral \\
\hline BF2 & $1.94^{\text {fghijk }}$ & $3.64^{\mathrm{a}}$ & $0.89^{\text {defghi }}$ & $7.06^{\mathrm{abc}}$ & $0.58^{\text {cde }}$ & $0.39^{\text {efgh }}$ & $0.28^{\mathrm{fg}}$ \\
\hline BR2 & $3.25^{\text {bcdefghij }}$ & $0.25^{\mathrm{b}}$ & $0.89^{\text {defghi }}$ & $6.94^{\mathrm{abc}}$ & $0.50^{\text {cde }}$ & $0.47^{\mathrm{efgh}}$ & $0.00^{\mathrm{g}}$ \\
\hline BR4 & $2.67^{\text {defghij }}$ & $0.22^{\mathrm{b}}$ & $0.83^{\text {efghi }}$ & $7.33^{\mathrm{ab}}$ & $0.33^{\text {cde }}$ & $0.22^{\text {fgh }}$ & $0.22^{\text {fg }}$ \\
\hline BR6 & $4.86^{\mathrm{abc}}$ & $0.00^{\mathrm{b}}$ & $0.69^{\text {ghi }}$ & $6.61^{\text {abcde }}$ & $0.33^{\text {cde }}$ & $0.72^{\text {def }}$ & $0.22^{\text {fg }}$ \\
\hline BR7 & $1.67^{\mathrm{ghijk}}$ & $0.00^{\mathrm{b}}$ & $0.94^{\text {defghi }}$ & $7.61^{\mathrm{a}}$ & $0.11^{\text {de }}$ & $0.00^{\mathrm{h}}$ & $0.11^{\mathrm{fg}}$ \\
\hline BR8 & $4.50^{\mathrm{abcd}}$ & $0.00^{\mathrm{b}}$ & $0.83^{\text {efghi }}$ & $7.36^{\mathrm{ab}}$ & $0.17^{\text {cde }}$ & $0.17^{\mathrm{fgh}}$ & $0.33^{\text {efg }}$ \\
\hline BR9 & $4.06^{\text {abcdef }}$ & $0.00^{\mathrm{b}}$ & $0.78^{\text {fghi }}$ & $7.36^{\mathrm{ab}}$ & $0.44^{\text {cde }}$ & $0.33^{\text {fgh }}$ & $0.17^{\mathrm{fg}}$ \\
\hline BG1 & $1.33^{\mathrm{jk}}$ & $0.00^{\mathrm{b}}$ & $1.56^{\mathrm{abc}}$ & $5.72^{\text {def }}$ & $0.67^{\mathrm{cd}}$ & $0.39^{\text {efgh }}$ & $0.67^{\text {defg }}$ \\
\hline BG2 & $2.22^{\text {efghij }}$ & $0.00^{\mathrm{b}}$ & $1.81^{\mathrm{a}}$ & $2.25^{\mathrm{hi}}$ & $1.42^{\mathrm{b}}$ & $2.06^{\mathrm{a}}$ & $2.06^{\mathrm{abc}}$ \\
\hline BG3 & $5.33^{\mathrm{ab}}$ & $0.00^{\mathrm{b}}$ & $1.39^{\text {abcde }}$ & $5.61^{\mathrm{ef}}$ & $0.72^{c}$ & $1.11^{\mathrm{cd}}$ & $0.75^{\text {def }}$ \\
\hline BG4 & $1.61^{\text {ghijk }}$ & $0.00^{\mathrm{b}}$ & $1.08^{\text {cdefghi }}$ & $3.36^{\mathrm{h}}$ & $1.94^{\mathrm{ab}}$ & $1.86^{\mathrm{ab}}$ & $1.33^{\mathrm{cd}}$ \\
\hline F1 & $0.00^{\mathrm{k}}$ & $4.33^{\mathrm{a}}$ & $0.97^{\text {cdefghi }}$ & $7.25^{\mathrm{ab}}$ & $0.22^{\text {cde }}$ & $0.11^{\text {gh }}$ & $0.00^{\mathrm{g}}$ \\
\hline $\mathrm{F} 2$ & $1.44^{\mathrm{hijk}}$ & $4.28^{\mathrm{a}}$ & $1.28^{\text {abcdefg }}$ & $6.78^{\mathrm{abcd}}$ & $0.44^{\text {cde }}$ & $0.39^{\text {efgh }}$ & $0.39^{\mathrm{efg}}$ \\
\hline $\mathrm{R} 1$ & $6.17^{\mathrm{a}}$ & $0.083^{b}$ & $0.56^{\mathrm{i}}$ & $6.06^{\text {cdef }}$ & $0.33^{\text {cde }}$ & $0.33^{\mathrm{fgh}}$ & $0.39^{\mathrm{efg}}$ \\
\hline $\mathrm{R} 2$ & $3.06^{\text {cdefghij }}$ & $0.06^{\mathrm{b}}$ & $1.06^{\text {cdefghi }}$ & $6.33^{\text {bcdef }}$ & $0.47^{\text {cde }}$ & $0.28^{\text {fgh }}$ & $0.33^{\mathrm{efg}}$ \\
\hline R3 & $3.67^{\text {bcdefg }}$ & $0.00^{\mathrm{b}}$ & $0.67^{\mathrm{hi}}$ & $6.94^{\mathrm{abc}}$ & $0.06^{\mathrm{e}}$ & $0.28^{\mathrm{fgh}}$ & $0.11^{\mathrm{fg}}$ \\
\hline R4 & $2.33^{\text {defghij }}$ & $0.22^{\mathrm{b}}$ & $0.61^{\mathrm{hi}}$ & $7.00^{\mathrm{abc}}$ & $0.28^{\text {cde }}$ & $0.33^{\text {fgh }}$ & $0.11^{\mathrm{fg}}$ \\
\hline R5 & $4.17^{\text {abcde }}$ & $0.00^{\mathrm{b}}$ & $0.83^{\text {efghi }}$ & $7.17^{\mathrm{ab}}$ & $0.28^{\text {cde }}$ & $0.11^{\text {gh }}$ & $0.50^{\mathrm{efg}}$ \\
\hline R6 & $3.53^{\text {bcdefghi }}$ & $0.00^{\mathrm{b}}$ & $0.72^{\text {ghi }}$ & $7.28^{\mathrm{ab}}$ & $0.33^{\text {cde }}$ & $0.28^{\mathrm{fgh}}$ & $0.33^{\mathrm{efg}}$ \\
\hline R7 & $3.61^{\text {bcdefgh }}$ & $0.00^{\mathrm{b}}$ & $0.89^{\text {defghi }}$ & $6.94^{\mathrm{abc}}$ & $0.44^{\text {cde }}$ & $0.44^{\mathrm{efgh}}$ & $0.22^{\mathrm{fg}}$ \\
\hline R8 & $3.61^{\text {bcdefgh }}$ & $0.00^{\mathrm{b}}$ & $0.94^{\text {defghi }}$ & $7.56^{\mathrm{a}}$ & $0.06^{\mathrm{e}}$ & $0.11^{\text {gh }}$ & $0.33^{\text {efg }}$ \\
\hline R9 & $2.72^{\text {cdefghij }}$ & $0.00^{\mathrm{b}}$ & $1.03^{\text {cdefghi }}$ & $7.00^{\mathrm{abc}}$ & $0.44^{\text {cde }}$ & $0.39^{\text {efgh }}$ & $0.11^{\mathrm{fg}}$ \\
\hline G1 & $1.22^{\mathrm{jk}}$ & $0.00^{\mathrm{b}}$ & $1.33^{\text {abcdef }}$ & $5.97^{\text {cdef }}$ & $0.67^{\mathrm{cd}}$ & $0.67^{\text {defg }}$ & $1.03^{\text {de }}$ \\
\hline G2 & $1.22^{\mathrm{jk}}$ & $0.00^{\mathrm{b}}$ & $1.72^{\mathrm{ab}}$ & $2.86^{\mathrm{h}}$ & $1.83^{\mathrm{ab}}$ & $1.89^{\mathrm{ab}}$ & $2.28^{\mathrm{ab}}$ \\
\hline G3 & $6.17^{\mathrm{a}}$ & $0.00^{\mathrm{b}}$ & $1.28^{\text {abcdefg }}$ & $5.44^{\mathrm{fg}}$ & $0.67^{\mathrm{cd}}$ & $0.94^{\text {cde }}$ & $0.44^{\mathrm{efg}}$ \\
\hline G4 & $1.39^{\mathrm{ijk}}$ & $0.00^{\mathrm{b}}$ & $1.69^{\mathrm{ab}}$ & $4.5^{\mathrm{g}}$ & $1.3889^{\mathrm{b}}$ & $2.19^{\mathrm{a}}$ & $0.44^{\mathrm{efg}}$ \\
\hline W1 & $4.89^{\mathrm{abc}}$ & $0.19^{b}$ & $1.47^{\mathrm{abcd}}$ & $2.72^{\mathrm{h}}$ & $2.25^{\mathrm{a}}$ & $1.33^{\mathrm{bc}}$ & $1.94^{\mathrm{bc}}$ \\
\hline W2 & $4.03^{\mathrm{abcdef}}$ & $0.00^{\mathrm{b}}$ & $1.17^{\text {bcdefgh }}$ & $1.56^{\mathrm{i}}$ & $0.61^{\text {cde }}$ & $0.22^{\text {fgh }}$ & $2.78^{\mathrm{a}}$ \\
\hline
\end{tabular}


Table V Results from ANOVA and T-grouping for all samples in removal evaluation based on each attribute.

Part 1.

\begin{tabular}{ccccccccc}
\hline Sample & 0_Shine & 1_Shine & 0_Coverage & 1_Coverage & 2_Coverage & 3_Coverage & 4_Coverage & $\begin{array}{c}\text { 4_Number } \\
\text { of strokes }\end{array}$ \\
\hline BF2 & $9.06 \mathrm{gh}$ & $8.44 \mathrm{~b}$ & $14.64 \mathrm{a}$ & $13.78 \mathrm{a}$ & $11.83 \mathrm{a}$ & $9.11 \mathrm{ab}$ & $4.81 \mathrm{~b}$ & $18.83 \mathrm{a}$ \\
BR2 & $12.33 \mathrm{bcdef}$ & $7.92 \mathrm{bc}$ & $14.39 \mathrm{a}$ & $10.00 \mathrm{~b}$ & $3.86 \mathrm{~cd}$ & $0.69 \mathrm{~d}$ & $0.00 \mathrm{c}$ & $1.33 \mathrm{bc}$ \\
BR4 & $12.72 \mathrm{abcd}$ & $6.78 \mathrm{cdef}$ & $14.31 \mathrm{a}$ & $9.56 \mathrm{bc}$ & $3.78 \mathrm{~cd}$ & $0.75 \mathrm{~d}$ & $0.00 \mathrm{c}$ & $1.44 \mathrm{bc}$ \\
BR6 & $13.22 \mathrm{a}$ & $7.33 \mathrm{bcde}$ & $14.94 \mathrm{a}$ & $8.89 \mathrm{bcdef}$ & $2.67 \mathrm{defg}$ & $0.08 \mathrm{~d}$ & $0.00 \mathrm{c}$ & $0.39 \mathrm{c}$ \\
BR7 & $13.42 \mathrm{a}$ & $7.31 \mathrm{bcde}$ & $15.00 \mathrm{a}$ & $9.61 \mathrm{bc}$ & $3.53 \mathrm{cde}$ & $0.50 \mathrm{~d}$ & $0.11 \mathrm{c}$ & $1.33 \mathrm{bc}$ \\
BR8 & $13.50 \mathrm{a}$ & $7.83 \mathrm{bcd}$ & $15.00 \mathrm{a}$ & $9.50 \mathrm{bcd}$ & $3.28 \mathrm{cdef}$ & $0.56 \mathrm{~d}$ & $0.00 \mathrm{c}$ & $1.11 \mathrm{bc}$ \\
BR9 & $13.36 \mathrm{a}$ & $7.92 \mathrm{bc}$ & $14.89 \mathrm{a}$ & $10.44 \mathrm{~b}$ & $4.53 \mathrm{c}$ & $2.11 \mathrm{c}$ & $0.00 \mathrm{c}$ & $2.72 \mathrm{~b}$ \\
F1 & $11.61 \mathrm{f}$ & $10.00 \mathrm{a}$ & $9.50 \mathrm{~b}$ & $9.03 \mathrm{bcde}$ & $8.56 \mathrm{~b}$ & $8.14 \mathrm{~b}$ & $7.36 \mathrm{a}$ & $19.28 \mathrm{a}$ \\
F2 & $8.86 \mathrm{~h}$ & $7.78 \mathrm{bcd}$ & $14.36 \mathrm{a}$ & $14.00 \mathrm{a}$ & $11.72 \mathrm{a}$ & $10.06 \mathrm{a}$ & $4.61 \mathrm{~b}$ & $19.00 \mathrm{a}$ \\
R1 & $9.89 \mathrm{~g}$ & $5.67 \mathrm{f}$ & $14.50 \mathrm{a}$ & $7.31 \mathrm{fgh}$ & $1.28 \mathrm{gh}$ & $0.47 \mathrm{~d}$ & $0.00 \mathrm{c}$ & $1.06 \mathrm{bc}$ \\
R2 & $12.11 \mathrm{cdef}$ & $7.17 \mathrm{bcde}$ & $14.47 \mathrm{a}$ & $7.83 \mathrm{defg}$ & $1.36 \mathrm{gh}$ & $0.00 \mathrm{~d}$ & $0.00 \mathrm{c}$ & $0.00 \mathrm{c}$ \\
R3 & $13.06 \mathrm{ab}$ & $6.61 \mathrm{cdef}$ & $14.92 \mathrm{a}$ & $5.92 \mathrm{~h}$ & $1.17 \mathrm{gh}$ & $0.00 \mathrm{~d}$ & $0.00 \mathrm{c}$ & $0.00 \mathrm{c}$ \\
R4 & $11.94 \mathrm{def}$ & $6.17 \mathrm{ef}$ & $14.83 \mathrm{a}$ & $8.00 \mathrm{cdefg}$ & $2.22 \mathrm{efg}$ & $0.28 \mathrm{~d}$ & $0.00 \mathrm{c}$ & $0.83 \mathrm{c}$ \\
R5 & $13.03 \mathrm{ab}$ & $7.83 \mathrm{bcd}$ & $15.00 \mathrm{a}$ & $7.67 \mathrm{efg}$ & $1.92 \mathrm{fgh}$ & $0.17 \mathrm{~d}$ & $0.00 \mathrm{c}$ & $0.22 \mathrm{c}$ \\
R6 & $11.81 \mathrm{ef}$ & $6.28 \mathrm{ef}$ & $14.61 \mathrm{a}$ & $6.89 \mathrm{gh}$ & $0.53 \mathrm{~h}$ & $0.00 \mathrm{~d}$ & $0.00 \mathrm{c}$ & $0.00 \mathrm{c}$ \\
R7 & $12.89 \mathrm{abc}$ & $6.78 \mathrm{cdef}$ & $14.83 \mathrm{a}$ & $7.31 \mathrm{fgh}$ & $1.28 \mathrm{gh}$ & $0.00 \mathrm{~d}$ & $0.00 \mathrm{c}$ & $0.00 \mathrm{c}$ \\
R8 & $12.89 \mathrm{abc}$ & $6.56 \mathrm{def}$ & $14.75 \mathrm{a}$ & $7.58 \mathrm{efgh}$ & $1.25 \mathrm{gh}$ & $0.00 \mathrm{~d}$ & $0.00 \mathrm{c}$ & $0.00 \mathrm{c}$ \\
R9 & $12.64 \mathrm{abcde}$ & $7.11 \mathrm{bcde}$ & $14.94 \mathrm{a}$ & $8.97 \mathrm{bcdef}$ & $3.36 \mathrm{cdef}$ & $0.08 \mathrm{~d}$ & $0.00 \mathrm{c}$ & $0.44 \mathrm{c}$
\end{tabular}

* Sample means with the same letter in a column are not significantly different $(\mathrm{P}<0.05)$.

**Each of the attributes in this table was significantly different among all the samples. $(\mathrm{P}<0.05)$ 
Table V Part 2.

\begin{tabular}{|c|c|c|c|c|c|c|c|c|c|}
\hline Sample & 0_Color_int & 1_Color_int & 2_Color_int & 3_Color_int & 4_Color_int & 1_Drag & 2_Drag & 3_Drag & 4_Drag \\
\hline BF2 & 8.06hij & 7.44gh & 6.81ab & $5.58 b$ & $3.64 b$ & $10.22 \mathrm{a}$ & $11.83 a$ & $11.61 \mathrm{a}$ & $11.06 \mathrm{~b}$ \\
\hline BR2 & $6.64 \mathrm{jk}$ & $5.69 \mathrm{j}$ & 4.14de & 0.69def & $0.00 \mathrm{c}$ & $8.19 b c$ & $7.50 \mathrm{~b}$ & $4.78 b$ & $1.47 \mathrm{~cd}$ \\
\hline BR4 & 8.39gh & 7.69gh & $5.28 \mathrm{bcd}$ & 1.28de & $0.00 \mathrm{c}$ & $8.25 b$ & 7.06bc & 3.53bcd & 1.17cde \\
\hline BR6 & $10.58 \mathrm{bc}$ & 8.78cdef & 4.89bcd & $0.06 f$ & $0.00 \mathrm{c}$ & $8.17 b c$ & 5.17defg & 2.33defg & $0.11 \mathrm{ef}$ \\
\hline BR7 & 10.92ab & $9.67 b c$ & $5.14 \mathrm{bcd}$ & $0.67 \mathrm{def}$ & $0.11 c$ & 7.72bcd & 5.83cdef & 3.22cde & 0.89cdef \\
\hline BR8 & 9.50def & 8.33defg & $4.86 \mathrm{~cd}$ & $1.36 \mathrm{~d}$ & $0.00 \mathrm{c}$ & 7.33bcde & 6.08bcde & 3.03cdef & 0.72def \\
\hline BR9 & $11.67 \mathrm{a}$ & $10.75 a$ & 6.61abc & $3.53 c$ & $0.00 \mathrm{c}$ & 7.67bcd & $6.58 \mathrm{bcd}$ & $4.00 \mathrm{bc}$ & $1.81 \mathrm{c}$ \\
\hline $\mathrm{F} 1$ & 8.14ghi & 8.31defg & $7.64 \mathrm{a}$ & $7.08 \mathrm{a}$ & $5.28 \mathrm{a}$ & $11.14 \mathrm{a}$ & $12.39 a$ & $12.33 a$ & $12.28 \mathrm{a}$ \\
\hline F2 & 7.53hij & 7.53gh & 7.31a & 6.67ab & $3.50 \mathrm{~b}$ & $10.61 a$ & $12.17 \mathrm{a}$ & $11.72 \mathrm{a}$ & $11.11 \mathrm{~b}$ \\
\hline $\mathrm{R} 1$ & 7.22ijk & 6.14ij & $1.72 \mathrm{f}$ & $0.44 \mathrm{def}$ & $0.00 \mathrm{c}$ & 6.53def & 4.47fgh & 1.69fghi & 0.83cdef \\
\hline $\mathrm{R} 2$ & $6.56 \mathrm{k}$ & $5.47 j$ & $1.06 \mathrm{f}$ & $0.00 \mathrm{f}$ & $0.00 \mathrm{c}$ & 6.78cdef & 4.94efg & 1.17ghi & $0.00 \mathrm{f}$ \\
\hline R3 & $8.42 \mathrm{gh}$ & 7.11hi & $1.17 f$ & $0.00 \mathrm{f}$ & $0.00 \mathrm{c}$ & $5.53 f$ & 3.92gh & 1.08ghi & $0.00 \mathrm{f}$ \\
\hline $\mathrm{R} 4$ & 8.94dfg & 7.78fgh & 2.58ef & $0.72 \mathrm{def}$ & $0.00 \mathrm{c}$ & 7.89bcd & 5.72cdef & 2.19defgh & $0.33 \mathrm{ef}$ \\
\hline $\mathrm{R} 5$ & 10.42bcd & 9.11bcde & $2.53 \mathrm{ef}$ & $0.06 \mathrm{f}$ & $0.00 \mathrm{c}$ & $5.94 \mathrm{ef}$ & 5.44defg & 2.06efgh & $0.17 \mathrm{ef}$ \\
\hline R6 & 9.78cde & 8.14efg & $0.86 \mathrm{f}$ & $0.00 \mathrm{f}$ & $0.00 \mathrm{c}$ & $5.44 \mathrm{f}$ & $3.00 \mathrm{~h}$ & $0.53 \mathrm{i}$ & $0.00 \mathrm{f}$ \\
\hline R7 & 10.81ab & $9.28 \mathrm{bcd}$ & $1.69 \mathrm{f}$ & $0.00 \mathrm{f}$ & $0.00 \mathrm{c}$ & $6.00 \mathrm{ef}$ & 3.97gh & 1.22ghi & $0.00 \mathrm{f}$ \\
\hline R8 & 8.83fg & 8.08fgh & $2.75 \mathrm{ef}$ & $0.00 \mathrm{f}$ & $0.00 \mathrm{c}$ & $5.83 f$ & 4.44fgh & 0.89hi & $0.00 \mathrm{f}$ \\
\hline R9 & $11.56 \mathrm{a}$ & 10.11ab & 5.78abcd & $0.08 \mathrm{ef}$ & $0.00 \mathrm{c}$ & $8.17 b c$ & 5.33defg & 2.44defg & $0.11 \mathrm{ef}$ \\
\hline
\end{tabular}


